\title{
PILOT GEOLOGICAL-GEOPHYSCHEMICAL SCHOOL COURSE "Bowels of the earth": PROBLEMS AND ACHIEVEMENTS
}

Reshetnyk Maria ${ }^{1}$, PhD. geol. Sc., Senior Researcher Scientist

Starokadomsky Dmitro, Ph.D. of chemistry $\backslash$ mater.sciences,

1 National Science and Natural History Museum of National Academy of Sciences of Ukraine

2 Chuiko Institute of Surface Chemistry of National Academy of Sciences of Ukraine

Email : reshetnykebigmir.net

Abstract: In this paper, the results of the experimental 5-years experimental course "Bowels of the earth" for students in schools in Kiev are presented. Classification of students according to the degree of teaching effectiveness was carried out. The problems in the conduct of the educational process are described.The statistics of students' success and their familiarity with geology as a function of training time are analyzed. A direct correlation was established between the duration of the course and the success of students, and the number of applicants to higher educational geological institutions.

Keywords. experimental course, geological knowledge, Interesting group of scholars, "not-promising passive" group, "hooligans", methods of activation, geological Olympiades and competitions.

\section{Introduction}

Scholarly endeavors in geoscience education are actual now [1-11]. Prospects and Requirements for a Workable Intern/Practicum in the Environmental Sciences in School were considered in [1]. Possibilities for practical training in camps were investigated in [2]. The Geology classes for non-geology majors, mostly juniors and seniors, became the basis for studying in [3].

Earth Systems, a new course developed expressly for pre-service middle school teachers, was developed in response to new Ohio Academic Content Standards [4]. During course, a practical works $\left(\mathrm{CO}_{2}\right.$-measurements from volcanoes MaunaLoa etc) and theoretical (global warming, and the latest ice age) was carried out [4].

Thompson et al [5] proposes a mini-lessons in elementary school classrooms, that were a strategic program created to help improve preservice elementary school teachers' attitudes toward science in a onesemester college class. Summary of answers to the open-ended, qualitative survey question created a maximal Number of positive responces (46 vs 10) and good lab and experiments/experiences (20 positive vs 7 negative), but weak level in "The rock and mineral identification final exam" (3 positive and 16 negative) [5, Table 1].

One of the priorities of school education is to develop a sense of responsibility for the preservation of national heritage, the most valuable component of which are the natural resources. Education of students on understanding of what is our resources, how to find or protect them - can be carried out not only in the framework of general education courses 
(where this issue is discussed in passing) or specialized circles (which involved only a small part students). This should be done by the introduction of a mandatory school program at the national level courses.

Now, geology as a discipline, acquires its own value [1] that require to understand the integrity of the world, the interconnectedness of the causes and consequences of various natural processes and phenomena with each other. For example, the development of mineral resources alters the ecological situation, which is displayed on people's health. Knowledge and understanding of the basic principles of the nature cycle can help in the preservation of Ecological Balance on the planet. For example, many scholars and students do not know anything about the underground water artesian cycles in nature, and believe that the water from the Jurassic strata of rocks originated in the time of dinosaurs!

Today in Kyiv in several schools are educated classes whith experimental course "Bowels of the earth" (initiated by Ukrainian Union of Geologists). Now, it is actual. According to sociological statistics, the results of a written survey it was found that high school students are wery poor base of geological knowledge. For example, they do not know who are geologists. As a result, in the last decade has seen a depopulation of ukrainian students on geological specialty.

\section{Statistic results of experimental course}

A valuable section of this study is the statistical and sociological data obtained.

You can see that the knowledge of geology among students before the start of training is insignificant. They are scooped mainly through out-of-school sources. After 5 years of study, the situation changes dramatically (Fig. 2.1): almost 90\% of the information (if you partially take into account Internet resources) was started by students from the teacher and school-related sources. It can be seen from Fig.2.2 that over 5 years, the level of achievement in geology has grown in all tested classes. The number of the lowest grades for 5 years is usually monotonously reduced, and the number of the highest grades rises (and often rises from zero). Statistical processing has proved the high efficiency of the experimental course to increase students' knowledge in the field of geology $($ fig.2.3) 


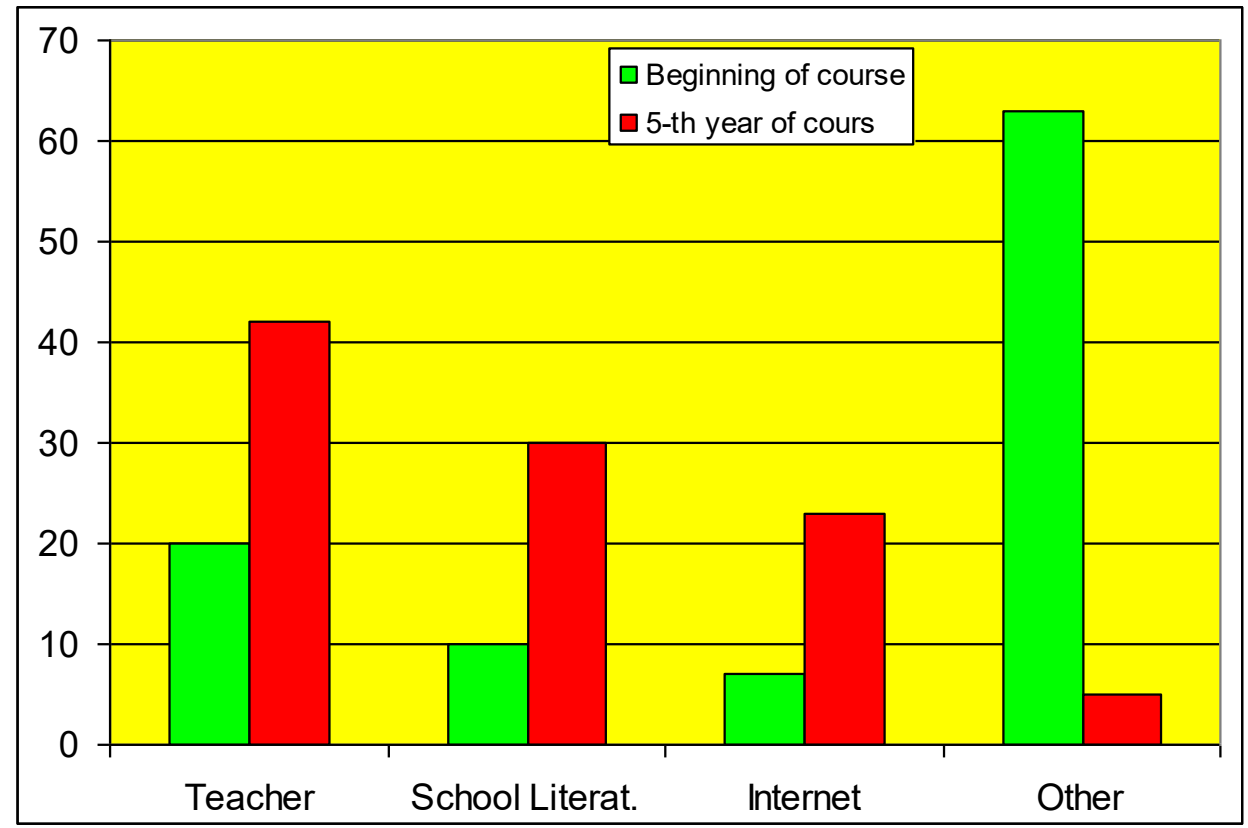

Fig. 2.1. Information ways about geology for our scholars.

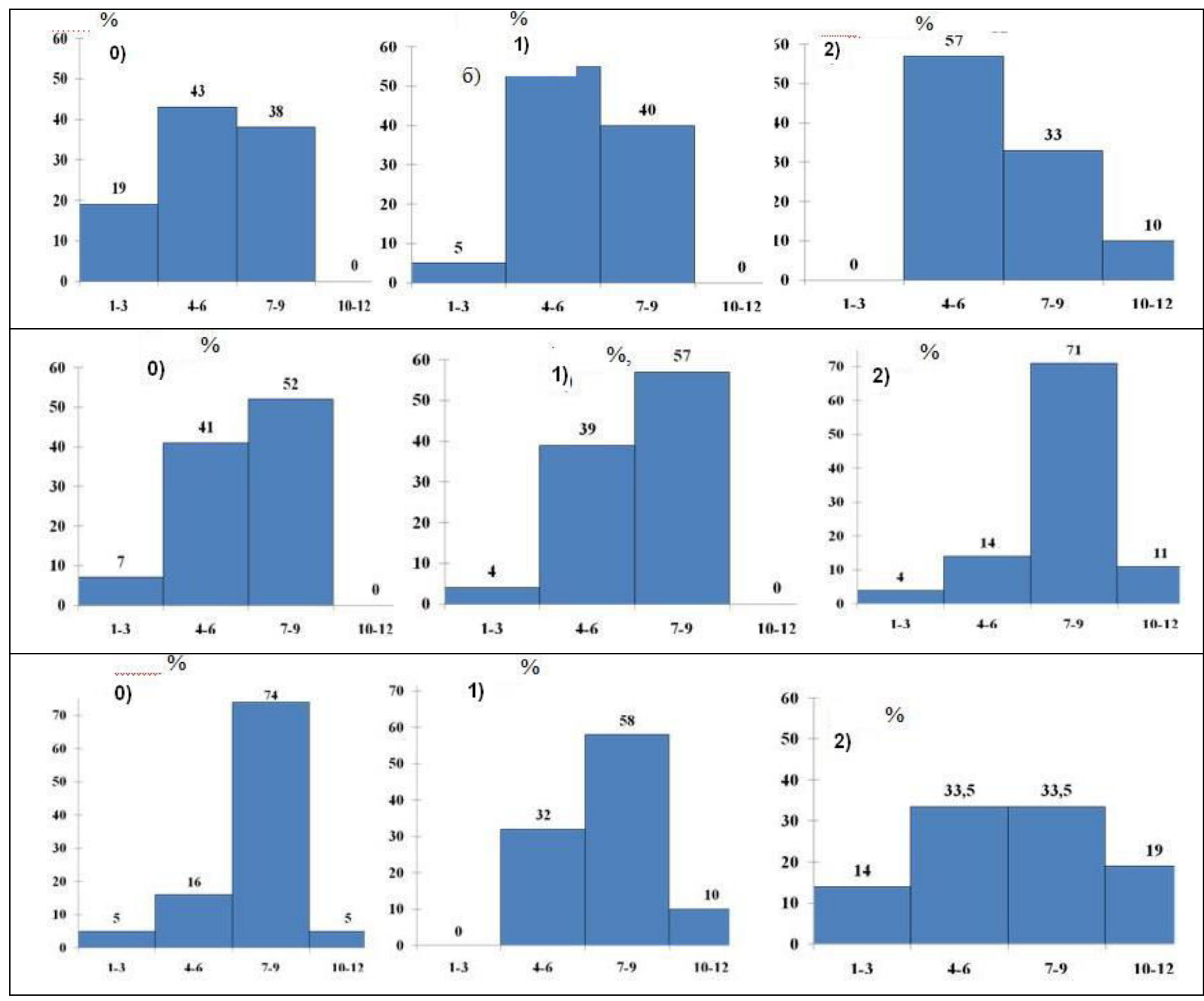

Fig.2.2. Ratio of scholars with different level of knowledge in geology. 0), 1), 2) - 0 (before experimental 
course), 1 and 2 years of course. 10-12 баллов соответствуют отличноц̆ оценке, 1-3 - наихудшей.

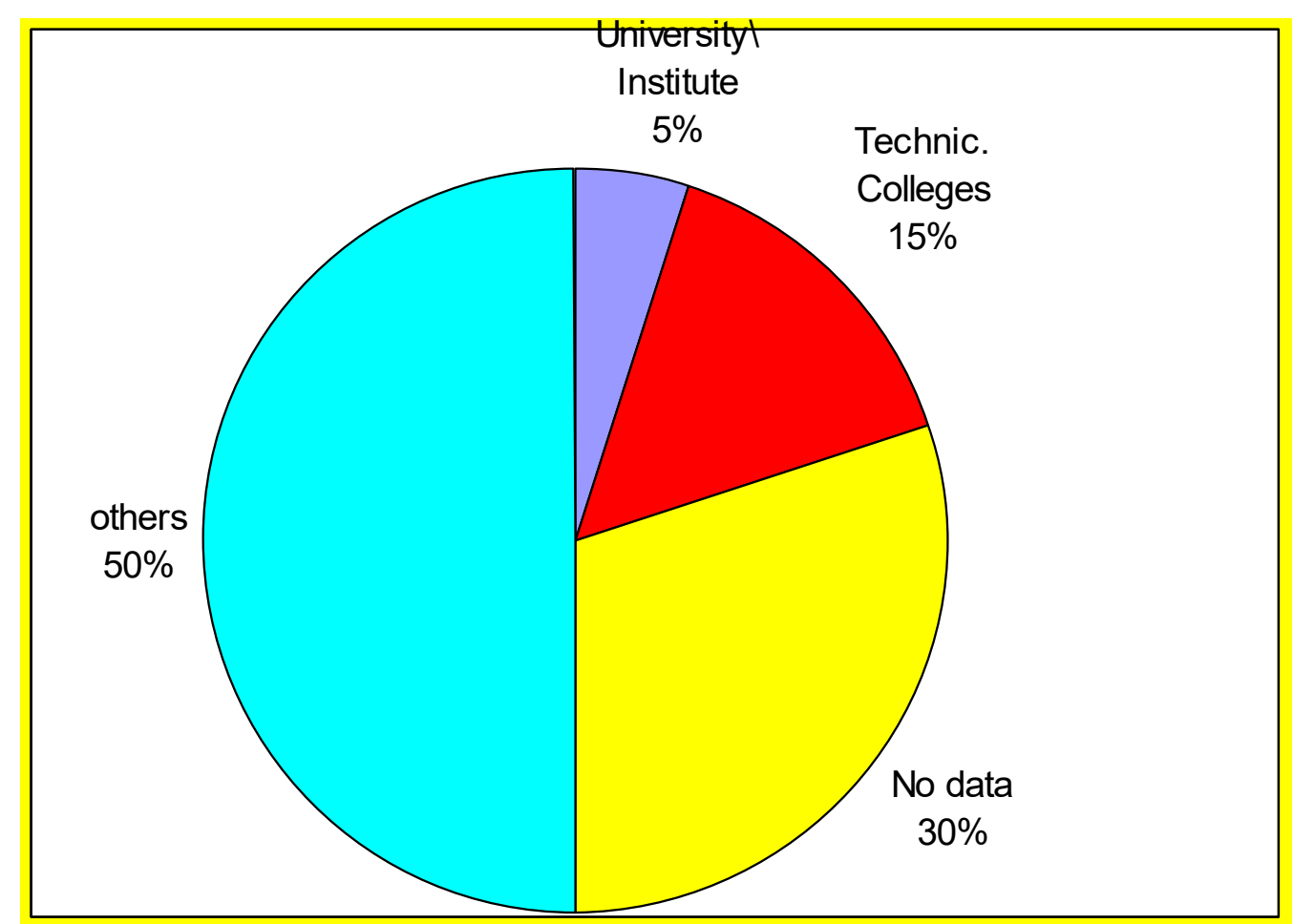

Fig. 2.3. The number of applicants to higher / technical geological institutions from the school No 13 .

\section{Results of experimental course: general remarks}

To understand the geological processes, the knowledge of chemistry, physics, mathematics, geography, biology is necessary. For example, the "bowels of the earth" course begins with the theme of origin of the Earth as part of the universe. Where it explains the origin of the chemical elements, the creation of the primary connections and even dust particles, the formation of large cosmic bodies and their interaction (using the knowledge from physics, astronomy and chemistry). To determine the age of the earth and rocks of the crust are necessary knowledge of physics, mathematics, biology. This contributes to a systematic scientific approach to the understanding of the environment.

However, most students do not know how to apply in practice (during the laboratory works on geology) available basic knowledge in chemistry, physics, geography.

Geology studies as natural processes as the properties of non-living natural substances - minerals, rocks, ores and gems. They transforms into a vivid source of information during the dialogue between teacher and student. In this study of the geology, special practices are needed. For example, for the study of mineral hardness Mohs scale is used, the determination of the magnetic susceptibility of rocks leads to the kappametry, for petrographic analysis the geological microscope is necessary, and to identify the forms and nature of geological bodies a compass is using. For the full scholar 
teaching of geology the laboratory facilities and equipment requires. The authors has conducted such studies in museums and laboratories, geological, chemical and physical institutions of National Academy of Sciences, on "in-field" voyages with expeditions of Ukrainian Union of Geologists. A number of laboratory and practical training stimulates scholar-s lively interest in the world around them.

A geology studying need the knowledge of geometry and geography. For example, geological maps and sections, threedimensional charts are flat and three-dimensional models of the geological environment, and their creation will certainly be based on the laws of geometry. Any geological research object is in situ consists of a set of points with coordinates and therefore must first be identified in the geographic coordinate system. Most of scholars cannot to analyse of three-dimensional figures, especially in geology (eg, various folds). Help comes from modeling clay and plasticine, modeling made of cardboard and foam. Students create models of different geological structures with their own hands or collect from fragments. Also, few school students know how to surrounding objects can be represented on the map, preserving their place position, distance between themselves etc. To train students create maps and charts should be spending a lot of practical training outside the classrooms. Course work outside of school more interesting for children, especially in warm weather.

During this work, we noticed how guys "relaxed" and began to listen better, and this is very important for today's children. High fatigue, confusion, congestion lessons, poor health leads to the fact that children simply can not work on the last lessons (the geology is placed in the school schedule usually 6-7-th lesson as a pilot course).

Very much attracted to children are computer modern technology - since the current generation grows surrounded by all kinds of digital devices (phones, tablets, computers). Just the desire to work with them, students are ready to perform tasks in geology. All students willingly perform tasks on the interactive whiteboard and create three-dimensional dynamic computer model (e.g. in Win serf) - this allows to apply the knowledge of algebra and informatics in practice, it is very pleasant to children of computer century. In the course Geoinformatics students learn the basics of programming. For example, to construct the maps they need to create an array with coordinates and intensity of the anomalous magnetic field at each point. The emphasis on geoinformatics is especially important because children are very proud of his ability to be programmed, and sometimes even look like computer literacy of some teachers.

Unfortunately interest in the subjects the students depends on their degree of advertising. For example, in 1990-s gained popularity professions of economists and lawyers, which 
stimulated interest in economics, mathematics and history. Today one of the most popular are the linguists - because the students is high interest in foreign languages. Geology in Ukraine today is not popular. Only in industrial areas (for example, the Donbass and Krivbass) guys tend to get knowledge on geology, as know of geologists with a good salary.

But geological profession is popular throughout the world. Many rich nations have good geological structure, for regular growing of their resource base. And up to now for land and ocean are white spots on the geological map, active exploration and search carries out. In order to advent of new technologies and geopolitical situations become actual exploration and development previously not economically viable for mining. For ukraine, the situation there is a need for the existence of geological sector. The high level of professionalism of Ukrainian geologists confirmed their demand for overseas. However, the Ukrainian government continues to ignore geologists, moreover there was a large-scale reduction of the state geological service in recent years.

To attract into the geological industry of young people need to popularize geology at the national level. For example, you can create youth series, where all the events would have unfolded around the geological circle or near new mines (or carriers, rocs etc). Or create a computer game that contains elements of education in geology. Wipe such intellectually rich movies and games today's popular movies and games for teenagers might have raised the general level of awareness of the geology students.

Those children who are interested in geology, have little or no opportunity to get acquainted with each other, because in fact the Ministry of Education does not hold competitions, workshops on geology. Geology can be in school education is included as a circle, and these circles are not provided Olympiad. In the Small Academy of Sciences has a Department of Earth, where there is a degree in geology. However, the section on geology IAS exist in several regional centers.

\section{Differentiation in education process}

In general, the children can be combined into groups and use different ways of working with each group. There are:

1). "Good children", promising for teaching (about 20\% of the class). It is interested in geology or disciplined honors. For this group need additional tasks to independent mastery of additional material of high complexity or the introduction of individual programs. In lesson it is advisable to give him an additional creative task. They can quickly prepare a response to an additional question in the classroom (as a rule due an Internet resource). This group of students has a proactive stance and can participate in extracurricular clubs, schools, seminars, competitions. Participation of students in Geology competitions where they see other geological classes, listen 
of successful geologists - increases their interest in next lessons.

However, our experience has shown that many of the "best students" in all subjects, are only interested in good official estimation, and do not work "overtime".

2). Interesting group. In each class is a group of students who work only for interest. They are those who for various reasons are interested in geology lesson, for example, watching scientific TV-channels ("Discovery" etc) or reading science-popular literature (american "Popular Mechanics", russo-ukrainian "Nauka@Technics" etc), want to know about gems, collect collection, and others. As a rule, they do not have large on the teacher-s estimation. They are interested in laboratory and practical training or gathering minerals collections, view and work with computer geological models.

3). The "not-promising passive" group. There are scholars without any interest as to geology as other courses. They are not-aggressive, but unable to teach all course, in most cases they have not a conspectus and shcolar-s journal. In optimistic scenario, not-promising children can teach a separate points of course.

4). "Bad boys and hooligans" (fig.2.4). It is a wery destructive group. The aim of their visit to school is to desorganise a teaching process. In particular, they use techniques and methods from special Internet sites and social networks. Accordingly, they are well organized, their roles in disrupting lessons are often distributed in advance. In these conditions, the teacher acts as a "victim on the hunt," and he has little chance of saving the learning process. Work with this group should follow the method of "anti-terrorist" operations - with the involvement of the directorate, parents, and, if necessary, the police. Most often this group does not give in to "taming", they must be isolated.

To increase the level of assimilation of the material the children from the perspective group may help to weaker students (check the correct execution of tasks and explain the wrong answers). Thus, the stronger children repeat material, and weaker children are not afraid to get a bad grade for their mistakes. guys often prompt each other during the writing of independent and control works. We let this help if we see it from the obvious harm to someone from the students or for the entire class. If there is a dialogue between the guys to clarify or recollection of only a few moments, you can dismiss it. But if there I s mindless copying certainly such activities should be prevented. Many children have a fear of writing in your own words, and even knowing the answer to the question (can verbally respond), they do not know how to properly formulate their thoughts on paper and that tend to simply write off already written by someone answer (sometimes incorrect).

As our conclusion, children learn best information through dialogue teacher-student. They cannot yet to search information in libraries, and even finding suitable literature can not extract information from it. Some children are 
difficult to understand written in a textbook. Schoolchildren for explain the material needed vivid analogy and colorful simplified illustrations. For each topic, we have created computer presentations. Material to remember guys were recorded in a special "geological journal" (on the right side turn written text on the left made drawings and diagrams).

Now, in ex-USSR we have not a textbooks on the geology (there are literature for technical schools and colleges). But schoolars requires another level of educational material. In addition, all materials must be executed according to scholar standards of textbooks. For scholars it is very important because the information in a familiar format is easier to digest. Therefore, for each lesson the author created small paragraphs, which were printed and distributed to the students for preparation to next lesson (we look the printed text are very helpful in understanding and memorizing new material). Also, the task was to teach the children themselves surf the Internet-libraries. To do this, set up special instructions, for example "how to correctly write the essay" or "how you must use an Internet-librairies". We concluded that many guys of 13-14 years fundamentally misunderstand what is abstractlessay. And they cannot even think that this is not simple copyright of text, but a form of research work (in which the student must find the issues in the topic, show own knowledge or to offer own solutions). Initially, the kids just brought the copying text found on any of first printed reference from the internet.

Favored by students affect teach by two teachers (binary lesson). For example, when the topic concerns the chemistry in geology, there is every reason to hold a major part of the lesson by teacher-chemist, whereas geologist will have some comments. We are working together with the scientists of Academy of Sciences to explain the new theme or laboratory and practical works (especially if they were conducted in academic institutions). The work of two teachers in geology is necessary not only to improve the perception of related topics (such as physico-chemical-geological). Two teachers contributes to the operating performance in the classroom. For example, one teacher works with strong students, and the other - with weak scholars. Students from these groups have as different starting level of training, as different speed of reference solutions. One teacher is difficult to engage with the class of 30 people totally different abilities, especially where course is experimental without manuals and textbooks. The second teacher is effective for very weak or problem scholars, who are not able to perform independent tasks or need to be repeated slow his explanation. For these children, we specifically picked light tasks that ideally (but not always) gradually, over time, become more complex to the normal level. For example, the second teacher ensures that they do records in a notebook. 
In each class there are "unruly Losers" who hold social niche "nihilists class" and strictly follow the maintenance of its authority. They are most often emanates intense or too "relaxed" atmosphere linked to deny the authority of the teacher. They are trying to organize collective absenteeism and class-strikes. Often they specifically inhibit or being drawn into its orbit interested and diligent students. In such cases, the effectiveness of the operational communication with parents, school administration, up to writing memos. As a rule, this work is time consuming, and under constant time pressure is not conducted adequately. In addition, their parents often ignore these complaints ( "if you are a teacher and you have him in your class to understand, just with tolerance"). In such cases, the videorecord of student behavior in the classroom is effective, as demonstration of this record to parentsldirection. But most effective and painless is demonstrative isolation of loose-students of total staff (for example to teacher's desk or on last seats), and not-include them in the game moments of class. In this case "bad boys" have not the benefits and privileges who have other children in the class.

Often these "bad boys" are "players of role" and simply do not know how to change. And sometimes they are based on useful initiatives. In our experience, once the holidays such "hooligans" suddenly voluntarily came to the Olympiad "Geology School" (that was ignored by most of best students). At the same time they behave decently and even demonstrated some knowledge on the subject (in lessons they demonstrated especially fully absence of any knowledge. And once, the leader of this "hooligans-group" prepared by himself the best essays on geology!

The extent and quality of teaching is different for each student. For example, some children possess better chemistry (for mineralogy, petrology) and those who are well aware of the geometry (for the structural geology). In addition, students can change their activity from lesson to lesson. Because of the pain, some "good students" may have not knowledge of the previous material, which is difficult to catch due to the lack of textbooks. These children need to copyllearn classmates abstracts and do all the homework. Theoretically, clarification of the material can give a teacher's consultation outside school hours, but as a rule all children go home after school. And here comes to the aid a remote work with students on the Internet. For example, e-mail correspondence (which they like - "as adults"), or a discussion on skype (effectively due to lack of classmates pressure). Outside of the class in the family circle, they may be more constructive. We did a newsletter presentations of lessons and requirements for homework by email. At the school site we present our lessons and e-geological library (some 
books scanned by us), and science-fiction video be copied on students flash-drives.

\section{Differentiation of main problems in education process.}

As a result of 3 years of teaching process we can classify all scholar-s problems in geology lessons in next typical groups.

1. "It is an optional subject, facultative". Geology lesson introduced as normal subject twice a week. Attend lesson should the whole class, it is not elective facultative, visited on request. However, the ratio of scholars to geology is similar to music, painting, health foundations, and others additive subjects. Many students are convinced that estimation on Geology does not go into the Schooltabel (report card ratings), or School Attestation. Also important argument to not-teach is that geology is not included in the examination items.

1A. Vulgarisation. The term "geology" is understood for many scholars, and therefore is associated with a confusing or even vulgar words (geelogy, gynecology and others.). Therefore, more understandable and useful to them could be called the subject, for example, as "Geophysics and Geochemistry."

2. "The last or first lesson." The lesson of geology as a pilot usually placed a last or first time (1-th or 7-th lesson), when students are tired, overexcited or are not cannot to listen in other motives. As a result, usually the end of lesson turns into a struggle for discipline.

3. "No of special cabinet". The geologist has no own class. In our case, lessons were held in the geography class in which it was allowed to leave the most severe patterns and layouts. However, we not allowed to use the computer and to store all samples or visual aids. Usually the computer, reagents and benefits for each lesson brings carried away by the teacher, that is discomfortable.

4. "You are not real teachers." The alienation of Geology from the usual school lessons does not allow students to evaluate teachers. In the context of poor scholar performance, this leads to doubts about the credibility of geology teacher. In fact, geologist is not a member of the teaching staff of the school. This is not a graduate of pedagogical university, and he often does not know the school pedagogy. As teacher-pluralist, geology teacher is not dedicated to the course of school activities, and as a result - does not have any influence over the students. 


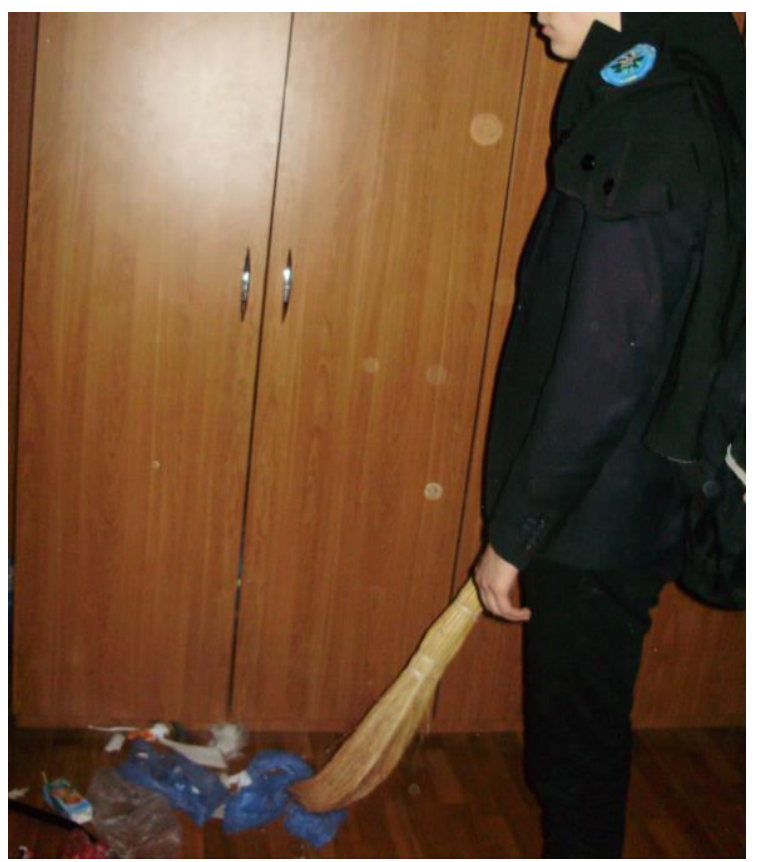

Fig.1. As a rule scholars ignores necessity of after-lesson sanitary of class. In this case, teacher blocked exit from class for cleaning.

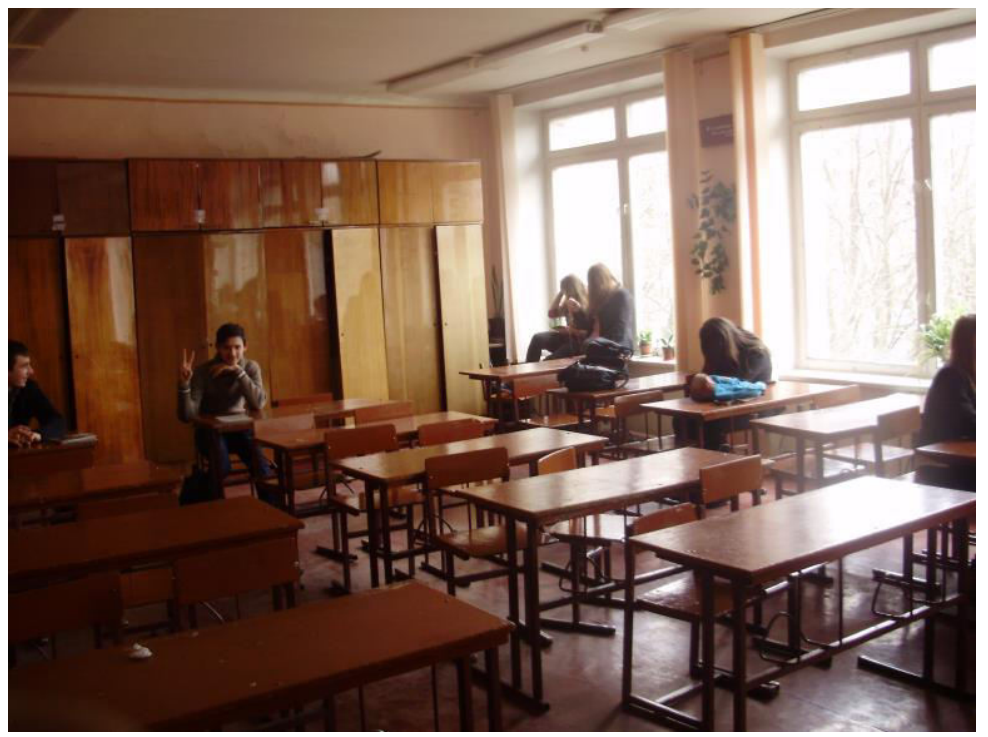

Fig.2. "Tea-for-two"... Only 6 scholars of 30-th are present in Geology, the rest were willfully coming "in basketball match" .

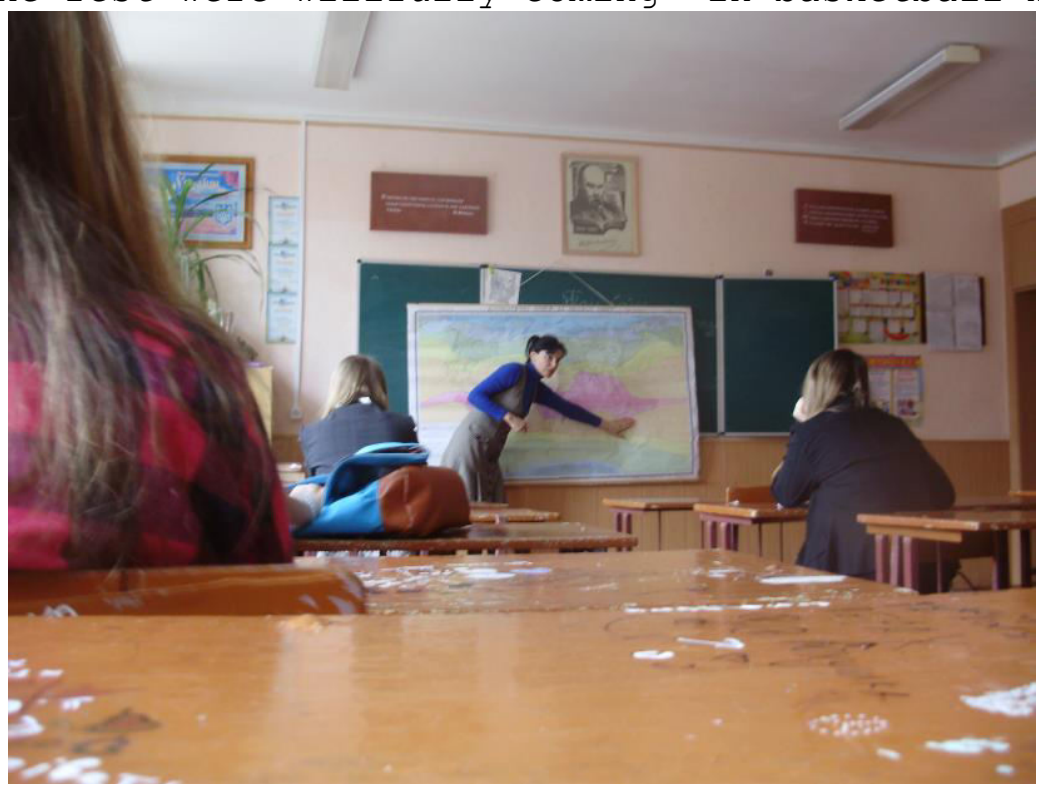


Fig.3. Up to $80 \%$ of class can be absent if Geology go as the last lesson...

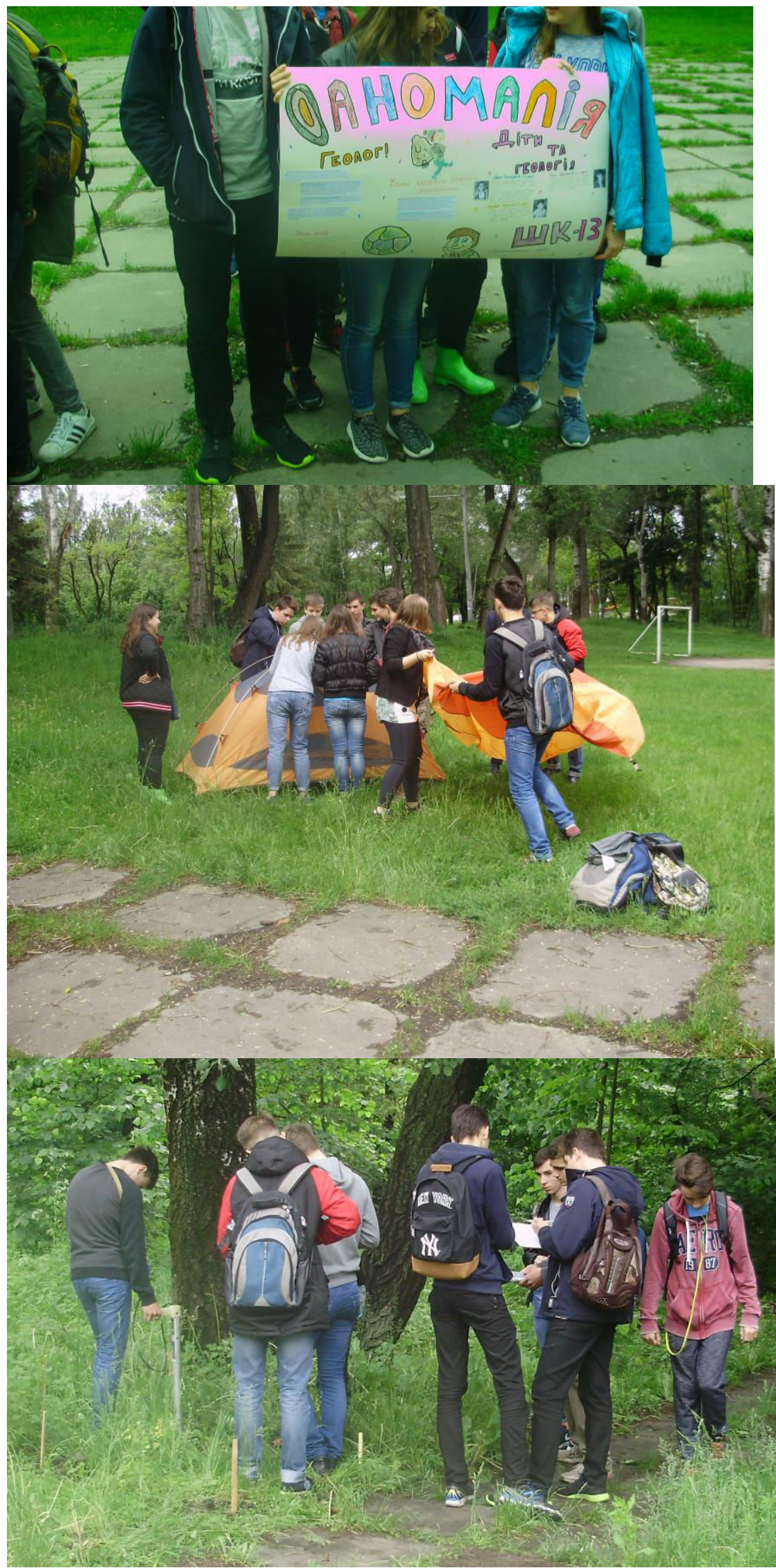

Fig.4 - 6. But lot of active scholars (or even "bad boys") are active on after-class competitions and olympiades on geology. 
As for the students, then there are many different aspects, for example:

A) Low level of knowledge for the perception of geology. The vast majority of students are not able to apply basic knowledge in chemistry, physics, geography. As a result, much of the material on the geology is not absorbed because of Geology is based on the knowledge in geography, physics, chemistry, biology.

B) Very weak discipline, that occurs naturally from weak perception. Often we have bad behavior of scholars, until the formation of a "theatral atmosphere" in the classroom. A low level of performance of pupils is also connected with the fact that the general fatigue children. Students are mostly not trained long and hard work. Discipline depends on the teacher's ability to create the proper atmosphere. Many teachers seek to silence the lesson through intimidation and shouting at students. As such, respect the teacher, like an older, more experienced man, no.

No motivation to learn. The majority of students have no interest in the subject of interest even after the demonstration of modern dynamic computer models of geological processes and geological museum displaying rare collections. Regularly there are questions, "why do we need all this?" And "let us go early."

Familiar methodological techniques restore order and discipline in the classroom and learning material in these conditions are not sufficient. In this situation, we used class of separation methods into groups based on subsequent encountered in their "bosses" [2]. In our experience, each class is divided into four groups.

\section{Conclusions.}

Geology as a special subject in the school course can be introduced as part of school education. However, lack of awareness of our students about the geology, the low level of popularisation of this specialty produce stereotype of the "uselessness" of geology.

Geology includes knowledge of different school courses and perfectly demonstrates their application in real life.

There is a need to create a variety of ways to attract students to the teaching of geology, in particular through the use of innovative educational and information and communication technologies.

The effectiveness of working with students of different levels of interest in the study of geology as a core academic subject is not possible by using differentiated approach. 


\section{References.}

1. R.H.Cutting, J.C.Hall. Requirements for a Workable Intern/Practicum in the Environmental Sciences: Experience for Careers and Graduate School // J. Geoscience Education. 3.2008, V.56, N2. //www.nagt.org/nagt/jge/abstracts/mar08.html\#v56p120

2. J.Saltzman. A.Paytan. Engaging First Grade Students in a Geoscience Campus . J. Geoscience Education. 9.2007, V.55, N.4, //www.nagt.org/nagt/jge/abstracts/sep07.html\#v55p326

3. M. Ali Tabidian. An Applied Alternative with Emphasis on Local Environmental Issues to a Traditional Term Paper for Environmental Geology Classes // J. Geoscience Education. 11.2007, V.55, N5 //www.nagt.org/nagt/jge/abstracts/nov07.html\#v55p381

4. W.Slattery, R.Teed, T.Cole, C.Davis. A Multi-Disciplinary Earth Systems Course Designed for Pre-Service Middle School Teachers.// // J. Geoscience Education. 9.2008 , V.56, $\mathrm{N}$ 4 . //www.nagt.org/nagt/jge/abstracts/may07.html\#v55p218

5. K.Thompson, B.R. Bickmore, C.R.Graham, S.C.Yanchar. Earth Science Mini-Lessons: A Service-Learning Strategy for Improving Attitudes Toward Science of Preservice Elementary Teachers.// J. Geoscience Education, v. 55, n. 3, May, 2007, p. 228-234

6. Kucher S.A. Do you need geology in school // Geography. №24. - 2005. - p. an electronic resource Access geo.1september.ru/article.php? ID $=200502405$
7 .
Geology
education.
Resources for
teachers.

http://www.dcnr.pa.gov/Education/GeologyEducation/Pages/default.aspx

8. Geologist Career Information with Education Requirements. Available at: http://study.com/geologist.html

9. Your Online Resource for Geology Degrees. A Geology Education An Overview. Available at: http://geologydegree.org/.

10. Elizabeth A. Holley. Engaging Engineering Students in Geoscience Through Case Studies and Active Learning. J.Geosciences Education. Volume 65, Issue 3 (August 2017).

10a. Reshetnyk M. Structure-geological informativity of Magnetic properties for rocks of Ukrainian shield. Diss.Ph.D.Geosciences. - Kyiv University, geological department, 2012. - $120 \mathrm{p}$.

10b. Reshetnyk M. Magnetic scanning method for granitoids of Ukrainiafn Shield. \\Earth Sciences. (2011).

11. Kristen St. John. IRB Protocol Starting Point for Those New to Geoscience Education Scholarship and Publication. J.Geosciences Education. Volume 64, Issue 2 (May 2016). 